\title{
Atrial Natriuretic Peptide Inhibits Mineralocorticoid Receptor Function in Rat Colonic Surface Cells
}

\author{
Gerri Schulman, ${ }^{\star}$ Rochelle Lindemeyer, ${ }^{\ddagger}$ Alan Barman, ${ }^{\star}$ Shaila Karnik, ${ }^{\star}$ and Christine P. Bastl ${ }^{\star}$ \\ Department of*Medicine, and ${ }^{\star}$ School of Dentistry, Temple University Health Sciences Center, Philadelphia, Pennsylvania 19140
}

\begin{abstract}
Atrial natriuretic peptide (ANP) inhibits and aldosterone (ALDO) stimulates $\mathrm{Na}$ conductive transport. Therefore, the effects of ANP and its second messenger cGMP on mineralocorticoid receptor (MR) function in rat colon surface and crypt cells were examined. $100 \mathrm{nM}$ 8-Br-cGMP decreased surface $\left[{ }^{3} \mathrm{H}\right] \mathrm{ALDO}$ binding by $42 \pm 4 \%$ but increased crypt $\left[{ }^{3} \mathrm{H}\right]$ ALDO binding by $52 \pm 16 \%$. ANP decreased surface $\left[{ }^{3} \mathrm{H}\right]$ ALDO binding by $\sim 50 \%$ after a 2.5 -h lag period but had no effect on crypt ALDO binding. ANP and cGMP rapidly ( $<15$ min) inhibited surface cell ALDO-induced MR nuclear translocation but did not affect crypt MR nuclear translocation. Inhibition of cGMP-dependent protein kinase with KT5823 blocked the inhibitory effects of ANP and 8-Br-cGMP on surface cell ALDO binding and MR nuclear translocation. In crypt, KT5823 increased baseline $\left[{ }^{3} \mathrm{H}\right] \mathrm{ALDO}$ binding but did not inhibit the stimulatory effect of exogenous cGMP. DEAE-cellulose chromatography and gel mobility shift assay showed that ANP did not inhibit surface MR activation. ANP inhibited ALDO stimulated short circuit current in distal colon. These data demonstrate cell-specific regulation of MR function. In surface cells, ANP rapidly inhibits MR nuclear translocation and ALDO-induced short circuit current. ANP inhibition of MR function may be an additional mechanism of ANP antagonism of Na reabsorption. (J. Clin. Invest. 1996. 98:157-166.) Key words: aldosterone - cyclic GMP - protein kinase - nuclear translocation • indirect immunofluorescence
\end{abstract}

\section{Introduction}

The mineralocorticoid receptor $(\mathrm{MR})^{1}$ is a member of the steroid/thyroid hormone superfamily of hormone-dependent transcriptional regulatory proteins (1). Based on homologies

Portions of this work have been published previously in abstract form (1992. J. Am. Soc. Nephrol. 3:508a; 1993. J. Am. Soc. Nephrol. 4:500a; 1994. J. Am. Soc. Nephrol. 5:669a).

Address correspondence to Gerri Schulman, M.D., Section of Nephrology, Temple University Hospital, 3401 North Broad Street, Philadelphia, PA 19140. Phone: 215-707-3381; FAX: 215-707-4148.

Received for publication 17 March 1995 and accepted in revised form 19 April 1996.

1. Abbreviations used in this paper: ANP, atrial natriuretic peptide; GR, glucocorticoid receptor; GRE, glucocorticoid response element; Isc, short circuit current; MR, mineralocorticoid receptor; NLS, nuclear localization signal; PD, potential difference; PKG, cGMP-dependent protein kinase; PR, progesterone receptor; VDR, vitamin D receptor.

J. Clin. Invest.

(C) The American Society for Clinical Investigation, Inc.

0021-9738/96/07/157/10 \$2.00

Volume 98, Number 1, July 1996, 157-166 in their predicted amino acid sequences, the MR is most closely related to the glucocorticoid (GR) and progesterone receptors (PR) (2). Steroid receptors cycle within a cell between several different forms. The form that binds hormone is a heteromeric complex consisting of receptor, the $90-\mathrm{kD}$ heat shock protein (hsp90), and several other lower molecular mass proteins (3-6). Association of GR and PR with hsp90 maintains these receptors in the unactivated steroid binding form (3). Steroid binding induces dissociation of hsp90 from GR, $\mathrm{PR}$, and $\mathrm{MR}$, and a conformational change in receptor protein exposing the DNA binding domain $(1,6,7)$. This process is known as activation or transformation. The activated receptor binds as a homodimer to specific DNA sequences known as response elements and stabilizes binding of RNA polymerase, thereby promoting transcription of target genes (6). Receptor then dissociates from chromatin and can be reassembled into the heteromeric unactivated form. The unliganded GR and MR are predominantly cytoplasmic because steroid is required for exposure of their dominant nuclear localization signal (NLS) whereas unliganded PR is predominantly nuclear because steroid is not required to expose its NLS (8-10). There are extensive data that specific protein kinases and phosphatases modulate multiple steps in GR and PR function including steroid binding, amount of receptor protein, stability of receptor mRNA, nuclear translocation, transcriptional activity, nuclear exit, and recycling of receptor back to the steroid-binding heteromer (for reviews see references 6 and 11). The effects of agents that alter protein kinase and/or phosphatase activity are kinase, cell, and/or receptor specific. The cell specificity is not surprising since there are both quantitative and qualitative differences in intracellular mediators in various cell types. Since growth factors and hormones that bind to cell surface receptors regulate specific kinase activity, it has been proposed that regulation of steroid hormone receptor function by kinases provides a mechanism for cross talk between cell surface receptors and intracellular steroid receptors $(11,12)$.

The role of kinases in regulation of MR function has not been extensively examined. Power et al. reported that cAMP induced PR mediated transcription of a target gene even in the absence of steroid but that cAMP had no effect on MR transcriptional activity (12). Horiuchi et al. reported that injection of rats in vivo with atrial natriuretic peptide (ANP) leads to a $50 \%$ decrease in renal cytosolic steroid-bound MR after $2 \mathrm{~h}$ (13). Since most actions of ANP are mediated by synthesis of cGMP and subsequent activation of cGMP-dependent protein kinase (PKG), these data suggest that cGMP rather than cAMP might regulate MR function $(14,15)$.

Therefore, this study was designed to characterize the effects of cGMP and ANP on MR function. Specifically, the goal was to determine if cGMP and ANP affected MR steroid binding, activation, DNA binding, or nuclear translocation and if alterations in MR function were associated with corresponding changes in aldosterone-induced $\mathrm{Na}$ reabsorption. Since regula- 
tion of receptor function is cell specific, results were compared in two different native target cells, colonic surface and crypt cells. Both cells contain MR and demonstrate steroid-dependent MR nuclear translocation (10). Surface cell MR mediates aldosterone-induced $\mathrm{Na}$ conductive transport (16). The function of crypt cell MR has not been established.

\section{Methods}

Cell isolation. Surface and crypt cells were isolated from distal colon of adrenalectomized rats by EDTA chelation and mechanical dissociation as previously described (10). Sprague-Dawley rats (200-250 grams) were adrenalectomized under methoxyflurane anesthesia 3-7 d before study and maintained on $2.5 \%$ dextrose $/ 0.45 \%$ saline and rat chow. Distal colon from 1-2 cm proximal to the insertion of the inferior mesenteric artery to the most distal accessible area was removed and washed free of intestinal contents with solution $\mathrm{A}(96 \mathrm{mM} \mathrm{NaCl}, 27$ $\mathrm{mM} \mathrm{Na}$ citrate, $1.5 \mathrm{mM} \mathrm{KCl}, 0.8 \mathrm{mM} \mathrm{KH}_{2} \mathrm{PO}_{4}, 5.6 \mathrm{mM} \mathrm{Na}_{2} \mathrm{HPO}_{4}$, $0.5 \%$ albumin, $1 \mathrm{mM}$ DTT, 5,000 U/liter penicillin, $5 \mathrm{mg} /$ liter streptomycin, $10 \mathrm{mg} /$ liter gentamicin and gassed with $95 \% \mathrm{O}_{2} / 5 \% \mathrm{CO}_{2}$, $\mathrm{pH}$ 7.4). Colon was filled with solution $\mathrm{A}(\sim 5-10 \mathrm{ml})$ and incubated at $30^{\circ} \mathrm{C}$ for $10 \mathrm{~min}$ in the presence of $95 \% \mathrm{O}_{2} / 5 \% \mathrm{CO}_{2}$. The solution which contained mucus and debris was discarded. The colon was rinsed and then filled with $5-10 \mathrm{ml}$ of solution $\mathrm{B}$ (1 mM EDTA, 115 $\mathrm{mM} \mathrm{NaCl}, 25 \mathrm{mM} \mathrm{NaHCO}, 2.4 \mathrm{mM} \mathrm{K}_{2} \mathrm{PO}_{4}, 0.4 \mathrm{mM} \mathrm{KH}_{2} \mathrm{PO}_{4}, 2.5$ $\mathrm{mM}$ L-glutamine, $0.5 \mathrm{mM} \beta$-OH-butyrate, $5,000 \mathrm{U} /$ liter penicillin, 5 $\mathrm{mg} /$ liter streptomycin, $10 \mathrm{mg} /$ liter gentamicin, $1 \mathrm{mM} \mathrm{DTT}, 0.5 \%$ albumin and gassed with $\left.95 \% \mathrm{O}_{2} / 5 \% \mathrm{CO}_{2}, \mathrm{pH} 7.4\right)$. Colon was incubated for $4 \mathrm{~min}$ at $30^{\circ} \mathrm{C}$ with $95 \% \mathrm{O}_{2} / 5 \% \mathrm{CO}_{2}$, then gently palpated for 3 min. The solution containing the cells was collected, adjusted to 4 $\mathrm{mM} \mathrm{CaCl} 2$, washed and resuspended in MEM minus phenol red to which glutamine, $\beta$-OH-butyrate, $1 \mathrm{mM}$ DTT, and antibiotics had been added. The colon was refilled with solution $\mathrm{B}$ and the process was repeated for 6-7 cycles except that colon was incubated for $3 \mathrm{~min}$ instead of $4 \mathrm{~min}$ for collections 3-7. The cells were incubated with type II collagenase (Sigma Immunochemicals, St. Louis, MO) 100 $\mathrm{mg} /$ liter for $15 \mathrm{~min}$ at $30^{\circ} \mathrm{C}$ in the presence of $95 \% \mathrm{O}_{2} / 5 \% \mathrm{CO}_{2}$. After this, cells were washed to remove collagenase, resuspended in MEM minus DTT at $4^{\circ} \mathrm{C}$, dispersed by pipetting, filtered through $30-\mu \mathrm{m}$ nylon mesh, and resuspended in MEM at a concentration of $\sim 10^{6}-10^{7}$ cells $/ \mathrm{ml}$. Cell viability as assessed by exclusion of trypan blue was routinely $>85 \%$. Surface cells were eluted in fractions 1 and 2 and deep crypt cells in fractions 5 and 6 . Cell separation was confirmed by histological examination of remnant colon, electron microscopy of eluted cells, alkaline phosphatase activity, and rates of $\left[{ }^{3} \mathrm{H}\right]$ leucine incorporation (10).

Steroid binding assay. Isolated cells were incubated with $10 \mathrm{nM}$ $\left[1,2,6,7-{ }^{3} \mathrm{H}\right]$ aldosterone $(93.7 \mathrm{Ci} / \mathrm{mmol}$, New England Nuclear, Boston, MA) plus 100 -fold molar excess of $11 \beta$-dihydroxy-6-methyl- $17 \alpha$ (propionyl)-androsta-1,4,6-triene-3-one (RU28362) to prevent crossover binding of aldosterone to the GR in the presence and absence of $100 \mathrm{nM} 8$-Br-cGMP (Sigma Immunochemicals) and $10^{-11} \mathrm{M}$ to $10^{-6} \mathrm{M}$ ANP (rat natriuretic peptide, Sigma Immunochemicals) at $30^{\circ} \mathrm{C}$ in the presence of $95 \% \mathrm{O}_{2} / 5 \% \mathrm{CO}_{2}$. Previous experiments demonstrated that $10 \mathrm{nM}\left[{ }^{3} \mathrm{H}\right]$ aldosterone is sufficient to saturate MR steroid binding sites (10). For experiments using KT5823 (Kamiya Biomedical Co., Thousand Oaks, CA), an inhibitor of PKG, $500 \mathrm{nM}$ KT5823 was added for $10 \mathrm{~min}$ at $4^{\circ} \mathrm{C}$ before addition of ANP or cGMP. Parallel incubation of cells with 1,000-fold excess unlabeled aldosterone was done to assess nonspecific binding. At the end of the incubation, cells were washed four times with PBS at $4^{\circ} \mathrm{C}$ to remove free steroid, lysed, transferred to scintillation vials with $5 \mathrm{ml}$ of Scintiverse II (Fisher Scientific Co., Pittsburgh, PA) and radioactivity was measured in a liquid scintillation spectrometer (LS2800; Beckman Instruments, Inc., Fullerton, CA) with a counting efficiency for tritium of $\sim 40 \%$. Specific $\left[{ }^{3} \mathrm{H}\right]$ aldosterone binding was calculated, data were normalized to cell number, and specific binding was compared in the presence and absence of cGMP and ANP (10).

Cell extractions. After incubation of cells with $10 \mathrm{nM}\left[{ }^{3} \mathrm{H}\right]$ aldosterone with and without $100 \mathrm{nM}$ ANP for $60 \mathrm{~min}$ at $30^{\circ} \mathrm{C}$, cells were resuspended in $50 \mathrm{mM}$ potassium phosphate (KP) buffer, $\mathrm{pH} 7.0$, containing $10 \mathrm{mM}$ sodium molybdate, $10 \mathrm{mM}$ sodium tungstate, and $10 \mathrm{mM}$ DTT. Cells were broken by freeze-thawing and mechanical homogenization. Cytosol was prepared by centrifuging the broken cell preparation at $105,000 \mathrm{~g}$ for $40 \mathrm{~min}$. The cytosol buffer also contained the following protease inhibitors: $10 \mathrm{mM}$ methyl-B-D-thiogalactoside, $1 \mathrm{mM}$ PMSF, $10 \mu \mathrm{g} / \mathrm{ml}$ leupeptin, $10 \mu \mathrm{g} / \mathrm{ml}$ aprotinin, $10 \mu \mathrm{g} /$ $\mathrm{ml}$ antipain, $10 \mu \mathrm{g} / \mathrm{ml}$ pepstatin, $1 \mathrm{mg} / \mathrm{ml} N$-tosyl-L-phenylalanine chloromethyl ketone, $0.5 \mathrm{mg} / \mathrm{ml} \mathrm{Na}-p$-tosyl-L-lysine chloromethyl ketone, $2 \mathrm{mM}$ EDTA, and $2 \mathrm{mM}$ EGTA. For whole cell extracts the broken cell preparation was adjusted to $400 \mathrm{mM} \mathrm{KCl}$ and incubated for $30 \mathrm{~min}$ at $4^{\circ} \mathrm{C}$ to extract chromatin-bound $\mathrm{MR}$, then centrifuged at $105,000 \mathrm{~g}$ for $40 \mathrm{~min}$ at $4^{\circ} \mathrm{C}$ in a Beckman ultracentrifuge. The supernatant whole cell extract was desalted by passage through a PD-10 column (Pharmacia Biotech Inc., Piscataway, NJ) equilibrated with $20 \mathrm{mM} \mathrm{KP}$, pH 7.0, containing $10 \mathrm{mM}$ molybdate, $10 \mathrm{mM}$ DTT, and 1 mM PMSF.

$D E A E$-cellulose chromatography. The whole cell extract was loaded on a 3-ml DEAE-cellulose column. The column was washed with $20 \mathrm{ml}$ of $20 \mathrm{mM} \mathrm{KP}$ buffer, activated MR was eluted with $20 \mathrm{ml}$ of $20 \mathrm{mM} \mathrm{KP}$ containing $100 \mathrm{mM} \mathrm{KCl}$ and then unactivated MR was eluted with $20 \mathrm{mM} \mathrm{KP}$ containing $250 \mathrm{mM} \mathrm{KCl}$. 1-ml fractions were collected, aliquots were mixed with Scintiverse II, and radioactivity was assayed by liquid scintillation counting. The total $\left[{ }^{3} \mathrm{H}\right]$ aldosterone dpms eluting in the activated $(100 \mathrm{mM} \mathrm{KCl})$ and unactivated $(250$ $\mathrm{mM} \mathrm{KCl}$ ) positions were added and the percentage of total MR eluting in the activated position was calculated.

Gel mobility shift assay. The DNA-binding ability of MR was assessed by gel mobility shift assay using a 90-bp fragment containing two glucocorticoid response elements (GRE) (TGTACAGGATGTTCT) separated by $31 \mathrm{bp}$. The GRE was cut from plasmid DNA using BamHI and HindIII and separated on a $1.8 \%$ low melting point agarose gel. The 90-bp GRE was identified by ethidium bromide staining and cut from the gel. The fragment was treated overnight with shrimp alkaline phosphatase and then was end-labeled with $\left[\alpha{ }^{32} \mathrm{P}\right]$ deoxy ATP using T4 polynucleotide kinase. For the mobility shift assay, 15,000-30,000 cpm of [ $\left.{ }^{32} \mathrm{P}\right]$ GRE was incubated with $30 \mu \mathrm{l}$ of cytosol for $60 \mathrm{~min}$ at $4^{\circ} \mathrm{C}$. Samples were electrophoresed on a $1 \%$ agarose gel, and the gel was dried and examined by autoradiography.

Indirect immunofluorescence. The intracellular localization of MR was assessed by whole cell indirect immunofluorescence using the MR antibody hMRsN as previously described $(10,17)$. This antibody recognizes unliganded, steroid-bound unactivated and activated MR and does not cross-react with the GR. Cells were incubated in the presence and absence of $100 \mathrm{nM}$ aldosterone, $100 \mathrm{nM} 8-\mathrm{Br}-\mathrm{cGMP}$, or $100 \mathrm{nM}$ ANP at $30^{\circ} \mathrm{C}$ for various time intervals. After the incubation, $200 \mu \mathrm{l}$ of $0.5-1 \times 10^{6}$ cells $/ \mathrm{ml}$ was spun onto microscope slides at 800 rpm for 6 min using a cytospin centrifuge. Slides were fixed in $70 \%$ methanol $/ 30 \%$ acetone for $10 \mathrm{~min}$ at $-20^{\circ} \mathrm{C}$, followed by $5 \mathrm{~min}$ at room temperature, then blocked with $5 \%$ normal goat serum/PBS for 30 min at room temperature. Aviden D blocking solution was added for $15 \mathrm{~min}$, removed by washing and then biotin blocking solution was added for $15 \mathrm{~min}$. Cells were then incubated with hMRsN $(15 \mu \mathrm{g} / \mathrm{ml})$ overnight at $4^{\circ} \mathrm{C}$. After the incubation with hMRsN, cells were incubated with biotinylated anti-rabbit IgG $(5 \mu \mathrm{g} / \mathrm{ml})$ for $2 \mathrm{~h}$ at room temperature, followed by a 1.5 -h incubation with Texas red Avidin $(20 \mu \mathrm{g} / \mathrm{ml})$. Slides were washed three times for $10 \mathrm{~min}$ in PBS after each incubation. Receptors were visualized with epifluorescence microscopy using appropriate filters and were photographed with Kodak Tri-X pan 400. Three parallel controls were performed by omitting hMRsN and incubating cells with preimmune serum, normal rabbit serum, or no primary antibody. All three controls consistently demonstrated little immunofluorescence compared with cells incubated with hMRsN. The degree of MR nuclear translocation as a 

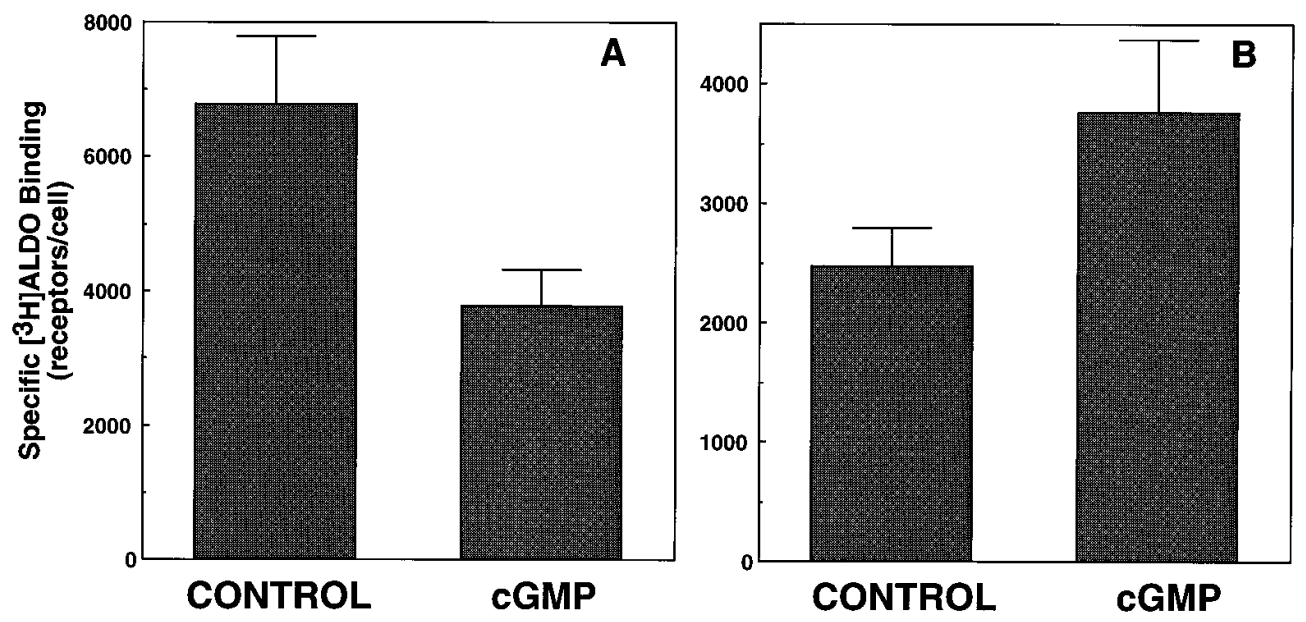

Figure 1. Effect of cGMP on surface $(A)$ and crypt $(B)$ specific $\left[{ }^{3} \mathrm{H}\right]$ aldosterone (ALDO) binding. Cells were incubated with $10 \mathrm{nM}\left[{ }^{3} \mathrm{H}\right] \mathrm{ALDO}$ in the presence and absence of $100 \mathrm{nM}$ 8 -Br-cGMP for $2.5 \mathrm{~h}$ at $30^{\circ} \mathrm{C}$. Data are presented as the mean \pm SEM for $n=7-9$. function of ANP concentration was assayed by incubating cells with $100 \mathrm{nM}$ ALDO with or without $10^{-11} \mathrm{M}$ to $10^{-6} \mathrm{M}$ ANP for $60 \mathrm{~min}$ and then counting the number of cells with exclusively cytoplasmic MR versus the number with nuclear MR. For each experimental condition, pictures were taken of representative microscopic fields and then two investigators independently graded each picture while blinded to the experimental condition. The number of cells with nuclear MR was divided by the total number of cells to calculate the percentage of cells with nuclear MR. The total number of cells counted for each concentration of ANP was 250-400 cells.

Measurement of short circuit current (Isc). To determine if ANP affected the aldosterone-induced sodium channel, rats were adrenalectomized 3-7 d before study and maintained on Dextrose $2.5 \% /$ $0.45 \%$ saline solution and standard Purina chow. Under methoxyflurane anesthesia colons were flushed clear with saline, removed and serosa stripped. The most distal segment which is the most aldosterone responsive segment and absorbs $\mathrm{Na}$ entirely by the Na-conductive channel in response to aldosterone was studied. Colons were mounted in water-jacketed Ussing chambers maintained at $37^{\circ} \mathrm{C}$ containing Ringer's bicarbonate as previously described (18). Tissue was studied under short-circuit conditions using automatic voltage clamps (DVC 1000 voltometer; World Precision Instruments, Inc., Sarasota, FL). Conductance was determined by dividing Isc by open circuit potential difference (PD). Three experimental conditions were evaluated ( $n=7$ for each group). Control tissue (ADX) was tissue which was not exposed to either aldosterone or ANP. With a separate group, baseline electrical parameters were measured for $25 \mathrm{~min}$ and then aldosterone was added to serosal and mucosal solutions to a final concentration of $5 \times 10^{-8} \mathrm{M}$ and electrical parameters were continuously measured. With the third group ANP $1 \times 10^{-9} \mathrm{M}$ was added to mucosal and serosal solutions when the tissue was mounted and after $25 \mathrm{~min}$ the tissue was exposed to $5 \times 10^{-8} \mathrm{M}$ aldosterone.

\section{Results}

Effects of cGMP and ANP on steroid binding. cGMP had opposite effects on the amount of steroid-bound MR in surface compared with crypt cells (Fig. 1). Control surface cell specific $\left[{ }^{3} \mathrm{H}\right]$ aldosterone binding was $6,769 \pm 1,019 \mathrm{MR} /$ cell, similar to the $B_{\max }$ determined by Scatchard analysis of 7,228 $\pm 1,067 \mathrm{MR} /$ cell $(10) \cdot\left[{ }^{3} \mathrm{H}\right]$ Aldosterone binding in surface cells decreased by $42 \pm 4 \%$ to $3,772 \pm 541$ receptors/cell after incubation with 100 nM 8 -Br-cGMP for $2.5 \mathrm{~h}(n=7, P<0.01$ control vs. cGMP). In crypt, control $\left[{ }^{3} \mathrm{H}\right]$ aldosterone binding was $2,467 \pm 332 \mathrm{MR} /$ cell, which is no different than the $\mathrm{B}_{\max }$ previously determined to be 2,299 $\pm 434 \mathrm{MR} /$ cell (10). Cyclic GMP increased specific $\left[{ }^{3} \mathrm{H}\right]$ aldosterone binding in crypt cells by $52 \pm 16 \%$ to
$3,753 \pm 617$ receptors/cell ( $n=9, P<0.02$ control vs. cGMP). Since ANP increases cGMP levels by stimulating guanylyl cyclase activity (14), surface and crypt cells were incubated with ANP for $2.5 \mathrm{~h}$. ANP had no effect on crypt cell MR steroid binding at any concentration tested $\left(10^{-11}-10^{-6} \mathrm{M}\right)$. In surface cells, ANP caused a concentration-dependent decrease in specific $\left[{ }^{3} \mathrm{H}\right]$ aldosterone binding by $-23 \pm 6 \%$ with $0.1 \mathrm{nM}(100$ pM) ANP to $-57 \pm 10 \%$ with $1 \mu \mathrm{M}$ ANP (Fig. 2). The decrease in aldosterone binding was statistically significant at $100 \mathrm{pM}$ ANP $(P<0.02, n=7)$. This decrease was not due to adverse effects of ANP on surface cell viability since cell viability was $\geq 90 \%$ in both control and ANP-exposed cells as indicated by exclusion of trypan blue. ANP-induced decreases in steroidbound MR required exposure of surface cells to ANP for 2.5-3 h (Fig. 3).

cGMP mediates its effects by stimulating PKG or by altering activity of cGMP-stimulated (type II) or cGMP-inhibited (type III) phosphodiesterases (19). To determine whether PKG mediated the opposite effects of cGMP on surface versus

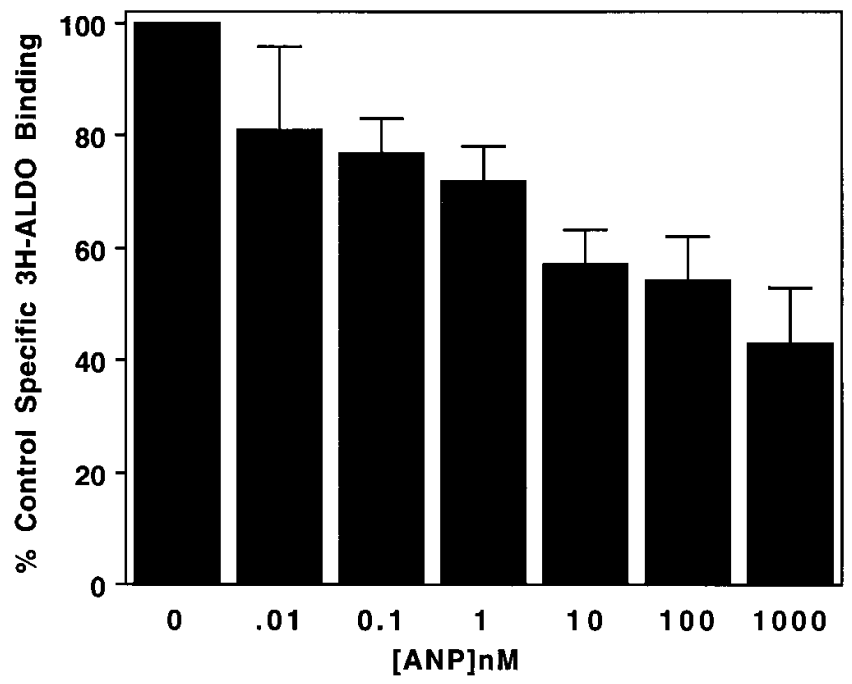

Figure 2. Dose response for ANP inhibition of [ $\left.{ }^{3} \mathrm{H}\right] \mathrm{ALDO}$ binding in surface cells. Cells were incubated with $10 \mathrm{nM}\left[{ }^{3} \mathrm{H}\right] \mathrm{ALDO}$ and increasing concentrations of ANP for $2.5 \mathrm{~h}$ at $30^{\circ} \mathrm{C}$. Data are presented as the mean \pm SEM of percent control specific $\left[{ }^{3} \mathrm{H}\right]$ ALDO binding for $n=7-10$. 


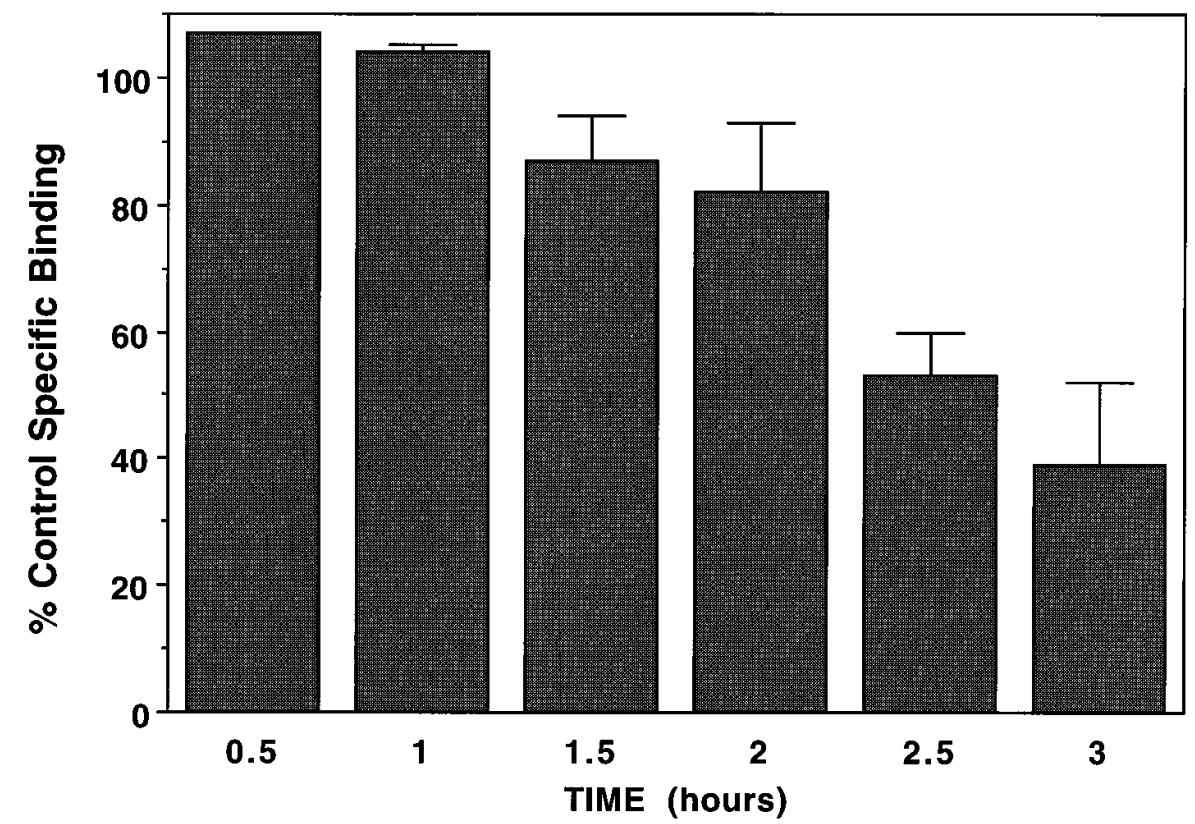

Figure 3. Time course of ANP inhibition of $\left[{ }^{3} \mathrm{H}\right]$ ALDO binding. Surface cells were incubated with $100 \mathrm{nM}$ ANP and $10 \mathrm{nM}$ $\left[{ }^{3} \mathrm{H}\right] \mathrm{ALDO}$ for various times. Results are presented as the mean $\pm \operatorname{SEM}(n=3-5)$ of percent specific $\left[{ }^{3} \mathrm{H}\right]$ ALDO binding in the presence versus absence of ANP. crypt cell steroid-bound MR, cells were incubated with KT5823, a selective inhibitor of PKG with a $K_{\mathrm{i}}$ for PKG of 0.23 $\mu \mathrm{M}$ versus a $K_{\mathrm{i}}$ for PKA of $>10 \mu \mathrm{M}$ and for PKC of $4 \mu \mathrm{M}$ (20). As shown in Fig. 4, KT5823 had little effect on baseline $\left[{ }^{3} \mathrm{H}\right]$ aldosterone binding but blocked the inhibitory effects of ANP and cGMP on surface cell MR. In contrast, in crypt cells KT5823 did not inhibit the stimulatory effect of cGMP on the amount of aldosterone-bound MR. However, KT5823 did increase baseline $\left[{ }^{3} \mathrm{H}\right]$ aldosterone-bound MR in crypt cells by $40 \pm 14 \%(n=6)$ compared with controls not exposed to exogenous cGMP.

Effect of cGMP and ANP on MR nuclear translocation. The effects of cGMP and ANP on MR nuclear translocation were examined by indirect immunofluorescence. In the absence of aldosterone, MR is cytoplasmic, and after exposure to steroid the MR translocates to the nucleus in both surface and crypt cells (10). In crypt cells, neither ANP nor cGMP had any effect on the cytoplasmic distribution of MR in the absence of aldosterone and neither agent inhibited MR nuclear translocation in the presence of aldosterone (Fig. 5). However, in surface cells both ANP and cGMP inhibited aldosterone-induced MR nuclear translocation (Fig. 6). ANP inhibition of surface cell MR nuclear translocation was obvious within $15 \mathrm{~min}$ and persisted for at least $1 \mathrm{~h}$ if ANP was continuously present (Fig. 7). To determine if ANP inhibited nuclear import or stimulated nuclear export, ANP was added only after the MR had translocated to the nucleus (Fig. 8, $A$ and $B$ ). The MR remained nuclear suggesting that ANP inhibited MR nuclear import. Reversibility of ANP inhibition of MR nuclear translocation was assessed by exposing surface cells to ANP and aldosterone to inhibit MR nuclear entry. After this, ANP was removed by washing and cells were exposed to aldosterone alone for $15 \mathrm{~min}$. As shown in Fig. 8, $C$ and $D$, within $15 \mathrm{~min}$ of removing ANP, the MR regained the ability to undergo aldosterone-dependent nuclear translocation. To determine if the inhibitory effects of ANP and cGMP on MR nuclear transloca-

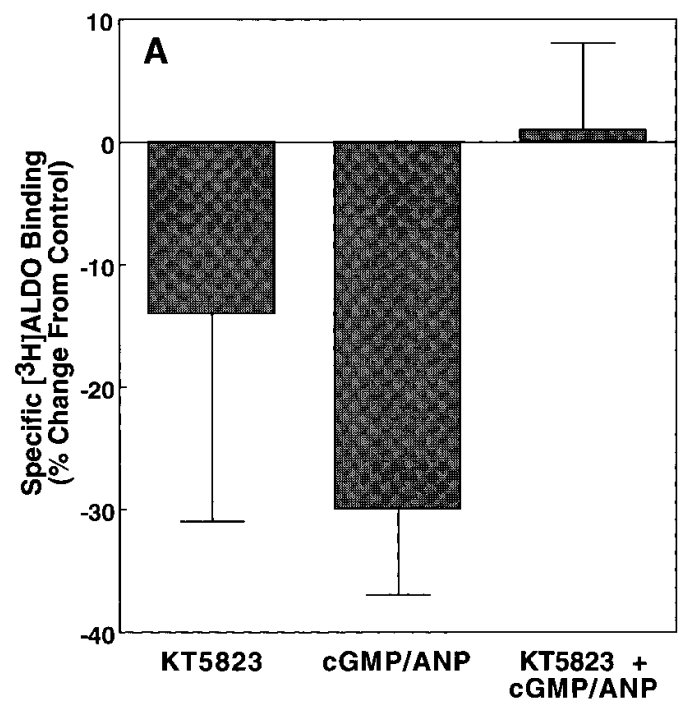

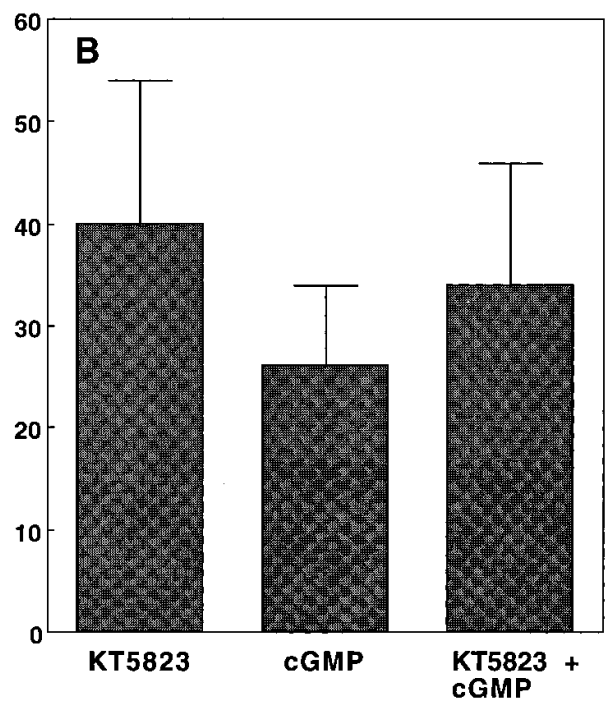

Figure 4. Effect of KT5823 on surface $(A)$ and crypt $(B)$ $\left[{ }^{3} \mathrm{H}\right]$ ALDO binding. Cells were incubated with $\left[{ }^{3} \mathrm{H}\right] \mathrm{ALDO}$ in the presence and absence of 500 nM KT5823. Data from surface cells exposed to either $100 \mathrm{nM}$ 8-Br-cGMP or $100 \mathrm{nM}$ ANP are pooled because results were the same with either ANP or cGMP. Crypt cells were exposed to KT5823 in the presence and absence of $100 \mathrm{nM} 8$-Br-cGMP. Results are presented as percent change from control (no KT5823, no cGMP/ANP) specific

$\left[{ }^{3} \mathrm{H}\right]$ ALDO binding for $n=4-6$. 


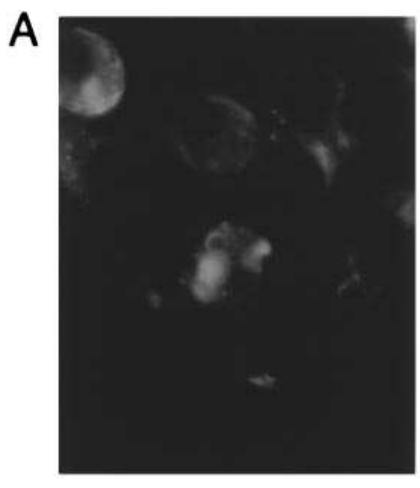

\section{B}

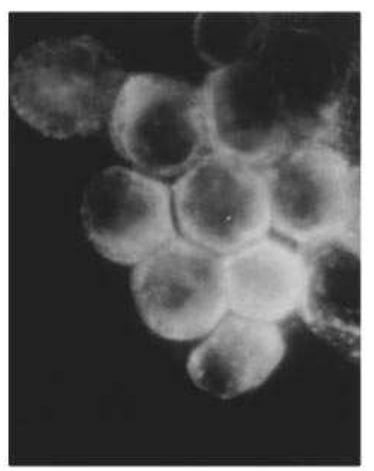

D

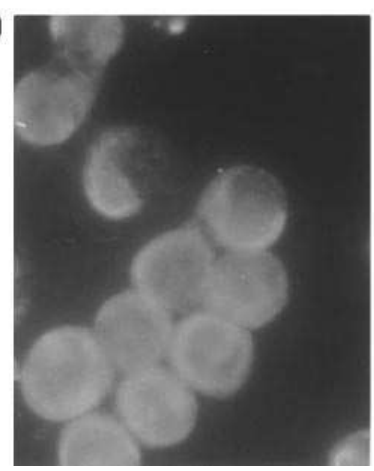

E

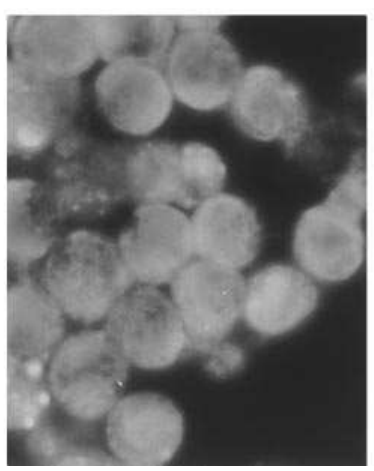

C

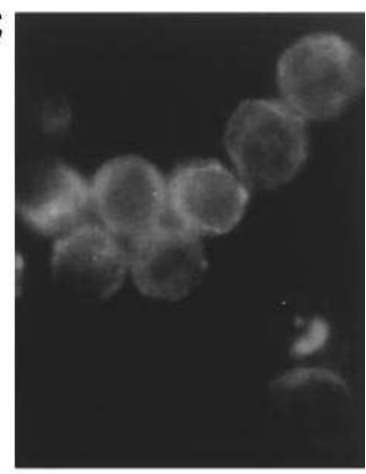

$\mathrm{F}$

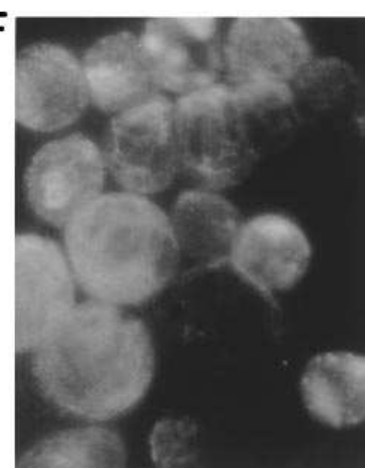

Figure 5. Effect of ANP and cGMP on crypt cell MR nuclear translocation. Crypt cells were incubated for $60 \mathrm{~min}$ at $30^{\circ} \mathrm{C}$ and processed for indirect immunofluorescence using $\mathrm{hMRsN}$ as described in Methods. $A$, No addition; $B, 100 \mathrm{nM}$ ANP; $C, 100$ nM 8-Br-cGMP; $D$, $100 \mathrm{nM}$ ALDO; $E, 100 \mathrm{nM}$ ALDO plus $100 \mathrm{nM}$ ANP; $F$, $100 \mathrm{nM}$ ALDO plus $100 \mathrm{nM}$ 8-Br-cGMP. tion were mediated by stimulation of PKG, cells were incubated with KT5823. As shown in Fig. 9, KT5823 had no effect on aldosterone-stimulated MR nuclear translocation. However, KT5823 prevented the inhibitory effects of ANP and cGMP on MR nuclear translocation. KT5823 had no effect on crypt cell MR nuclear translocation (data not shown). The dose-response relationship for ANP inhibition of surface cell
MR nuclear translocation was similar to that observed for ANP inhibition of aldosterone binding (Fig. 10). The percentage of cells with nuclear MR decreased from $71 \pm 3 \%$ in cells exposed to aldosterone in the absence of ANP to $46 \pm 7 \%$ in cells exposed to aldosterone plus 100 pM ANP. Maximal inhibition of MR nuclear translocation occurred at $100 \mathrm{nM}$ ANP. At this concentration, MR nuclear translocation was no differ-

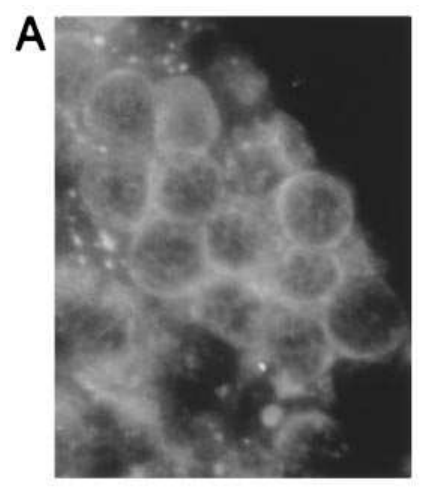

\section{B}
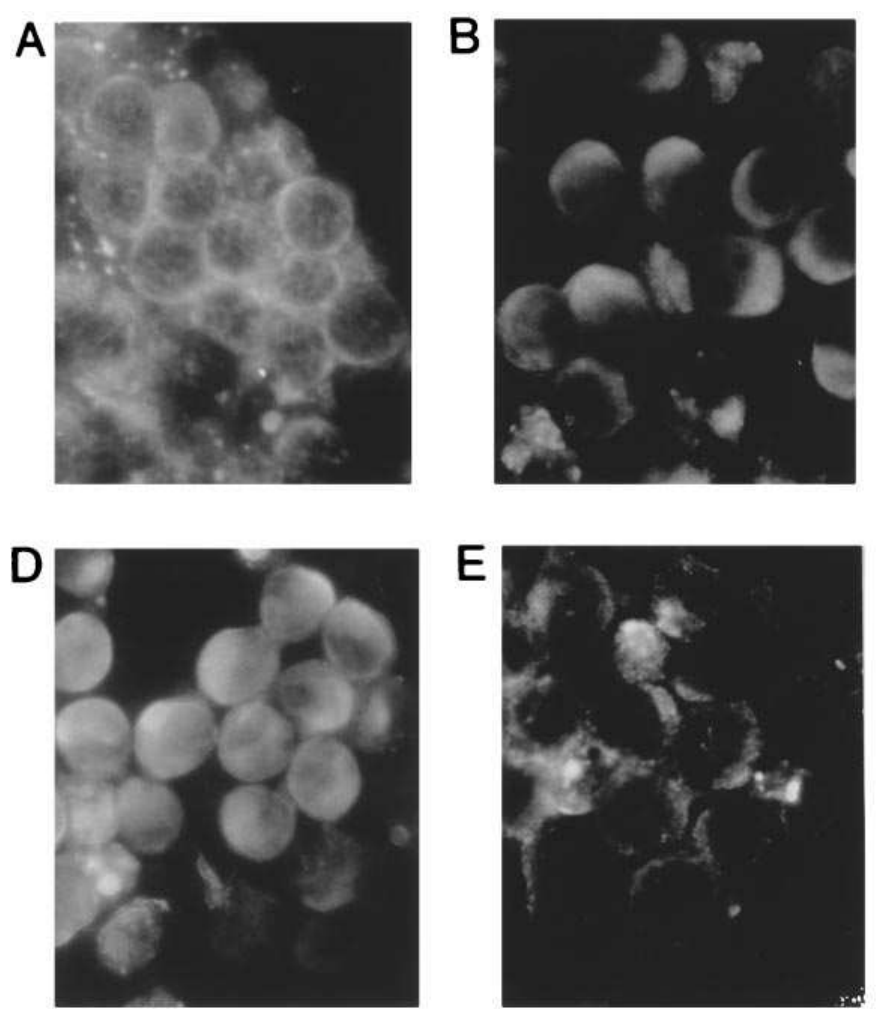

E

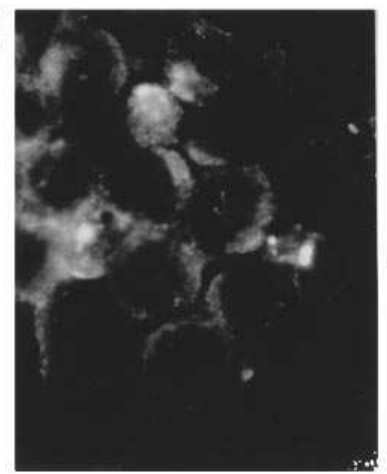

C

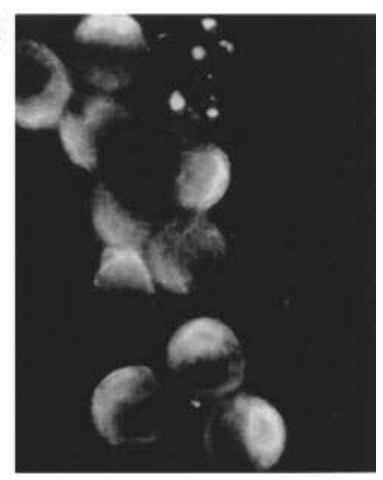

$\mathrm{F}$

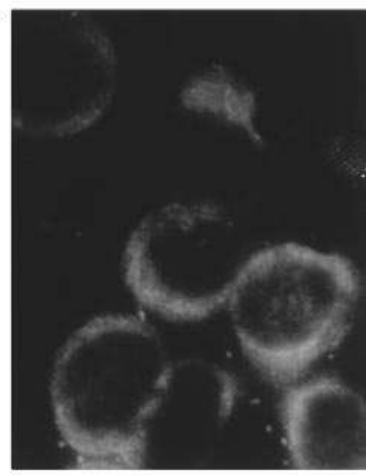

Figure 6. Effect of ANP and cGMP on surface cell MR nuclear translocation. Surface cells were incubated for $60 \mathrm{~min}$ at $30^{\circ} \mathrm{C}$ and processed for indirect immunofluorescence using hMRsN as described in Methods. $A$, No addition; $B, 100 \mathrm{nM}$ ANP; $C, 100 \mathrm{nM}$ 8-Br-cGMP; $D$, $100 \mathrm{nM}$ ALDO; $E, 100 \mathrm{nM}$ ALDO plus $100 \mathrm{nM}$ ANP; $F$, $100 \mathrm{nM}$ ALDO plus $100 \mathrm{nM}$ 8-Br-cGMP. 


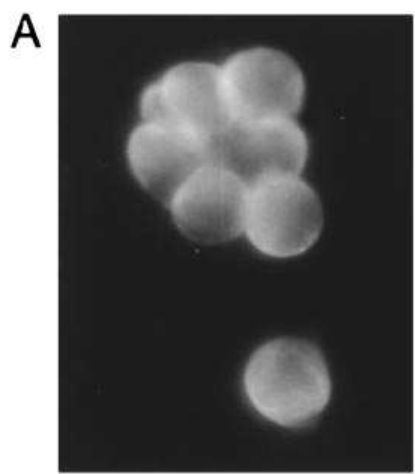

B
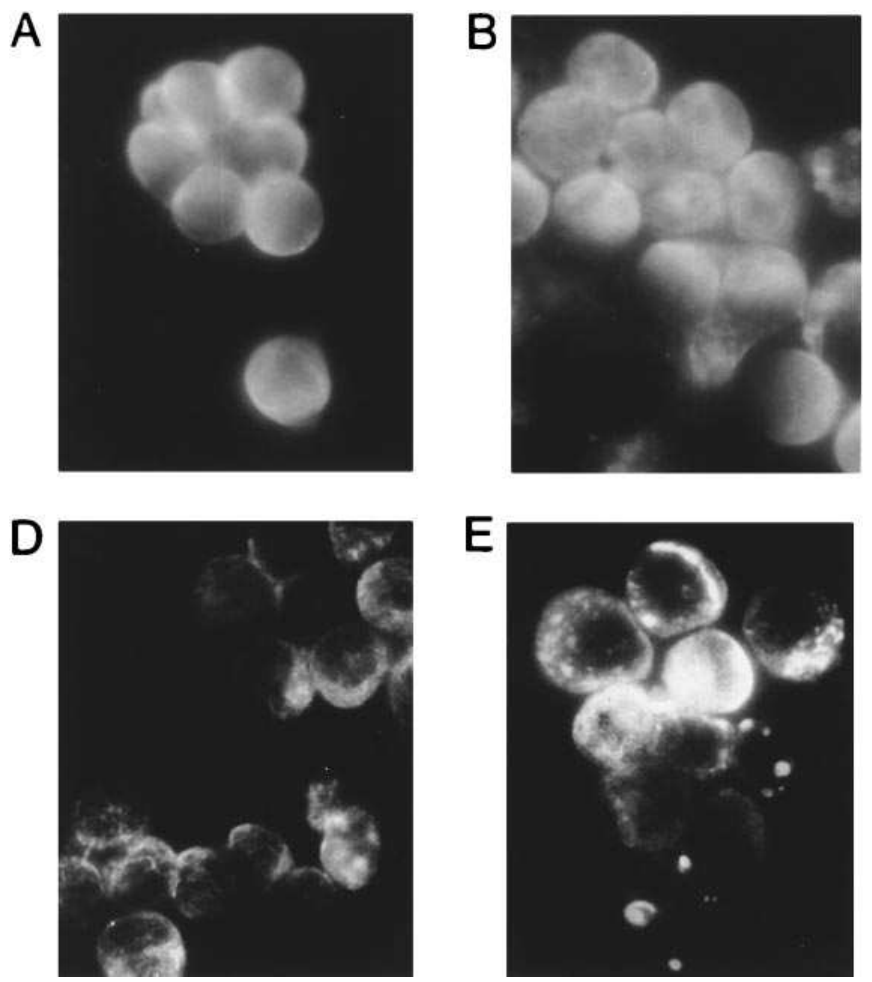

ent from that seen in cells not exposed to aldosterone (aldosterone plus $100 \mathrm{nM}$ ANP: $17 \pm 1 \%$ vs. no aldosterone: $15 \pm 1 \%$ ).

Effect of ANP on MR activation. ANP inhibition of MR nuclear translocation could reflect inhibition of MR activation. Activation causes a conformational change in receptor exposing more negative charges and resulting in elution of MR from DEAE-cellulose at a lower salt concentration (21). Therefore, activation was assessed by DEAE-cellulose chromatography
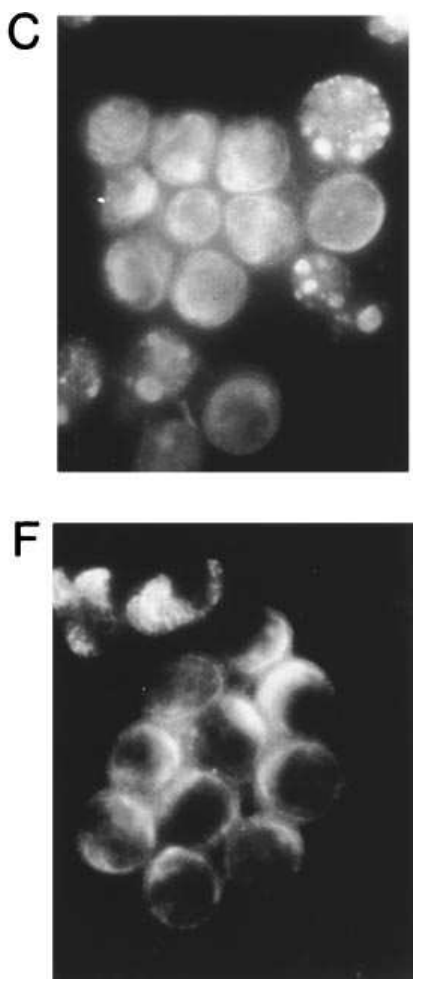

Figure 7. Time course of ANP inhibition of MR nuclear translocation. Surface cells were incubated with ALDO alone for 15 $\min (A), 30 \mathrm{~min}(B)$, and $60 \mathrm{~min}$ $(C)$ or with ALDO plus ANP for $15 \min (D), 30 \min (E)$, and 60 $\min (F)$.

of whole cell extracts. In control cells, $36 \pm 2 \%(n=3)$ of MR eluted in the activated position $(100 \mathrm{mM} \mathrm{KCl})$. In cells exposed to $100 \mathrm{nM}$ ANP for $60 \mathrm{~min}, 29 \pm 7 \%$ of MR was activated, suggesting that ANP does not inhibit MR activation (data not shown).

To confirm that ANP did not inhibit MR nuclear translocation by inhibiting activation, the ability of the MR trapped in the cytosol to bind to DNA was assessed by gel mobility shift

$\mathbf{A}$

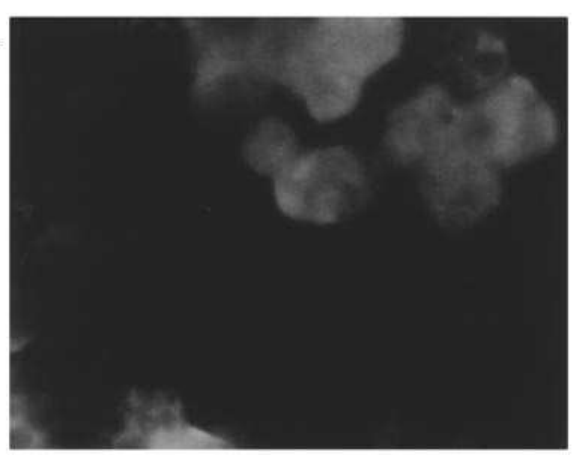

$\mathbf{C}$

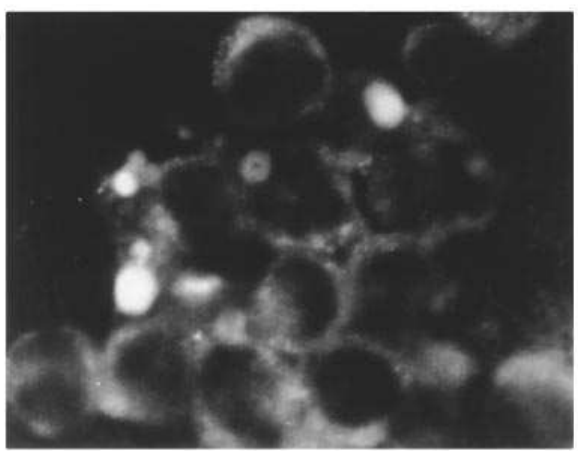

B

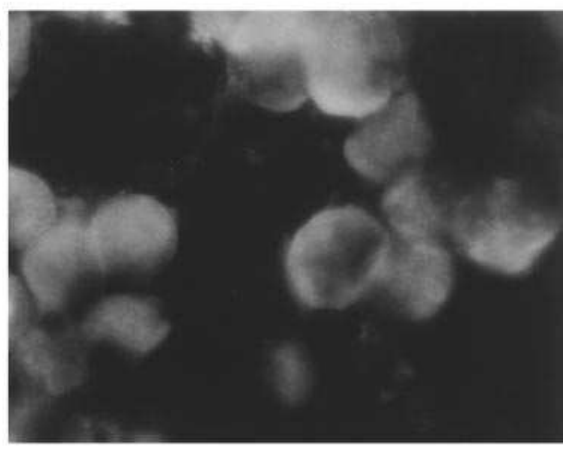

D

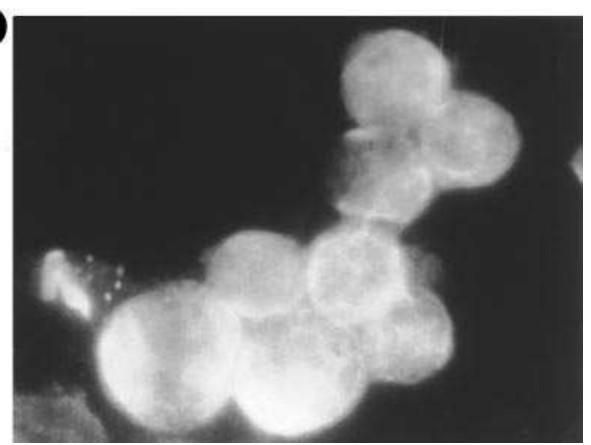

Figure 8. Reversibility of ANP inhibition of MR nuclear translocation in surface cells. Surface cells were exposed to $100 \mathrm{nM}$ ALDO alone for $15 \mathrm{~min}(A)$ followed by addition of $100 \mathrm{nM}$ ANP for 30 additional min (B). $C$ shows surface cells incubated with $100 \mathrm{nM}$ ALDO plus 100 nM ANP for $15 \mathrm{~min}$. Cells were then washed and incubated with ALDO alone for $15 \min (D)$. 
A

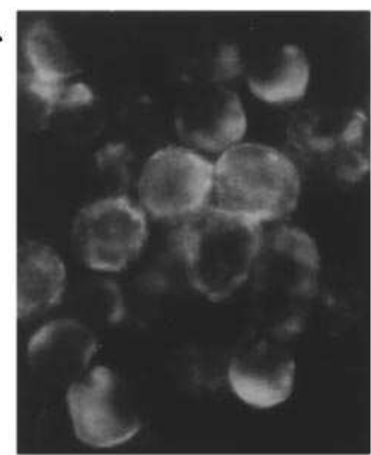

\section{D}

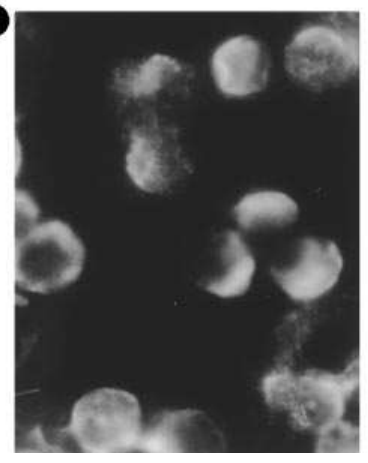

B

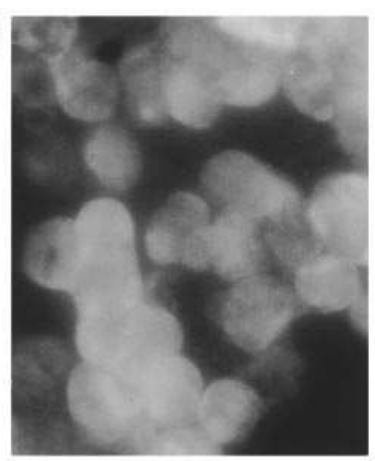

$\mathbf{E}$

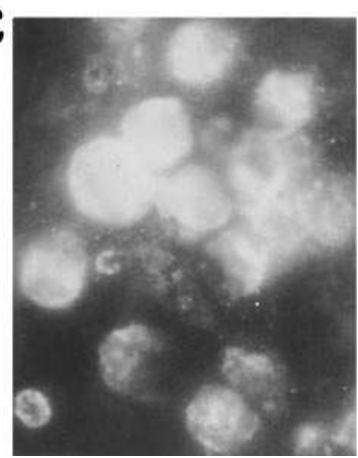

C

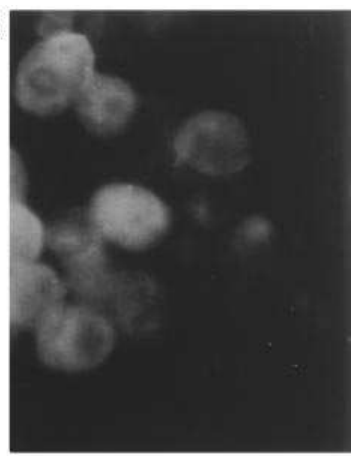

F

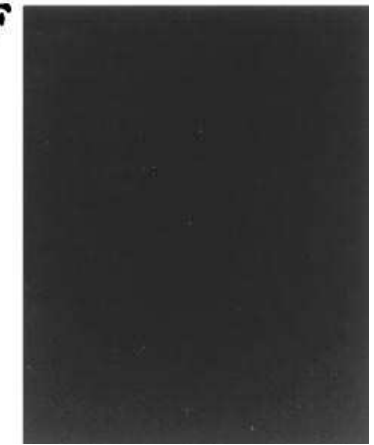

Figure 9. Effect of KT5823 on MR nuclear translocation in surface cells. $A$, ALDO plus ANP; $B$, ALDO plus ANP plus KT5823; $C$, ALDO plus KT5823; $D$, ALDO plus 8-Br-cGMP; $E$, ALDO plus 8-Br-cGMP plus KT5823; $F$, cells stained with normal rabbit serum instead of hMRsN. All incubations were for $1 \mathrm{~h}$ at $30^{\circ} \mathrm{C}$. assay. The MR, GR, PR, and androgen receptor share a common hormone response element (6). Therefore, MR binding to a ${ }^{32} \mathrm{P}$-labeled GRE was compared in the presence and absence of ANP (Fig. 11). As expected, MR from control cells exposed to neither aldosterone nor ANP did not bind to the GRE, indicating that MR remained unactivated (Fig. $11 A$, lane 3 ). In cells incubated with aldosterone alone (Fig. $11 A$, lane 5) the MR did bind to the GRE, confirming that aldoster-

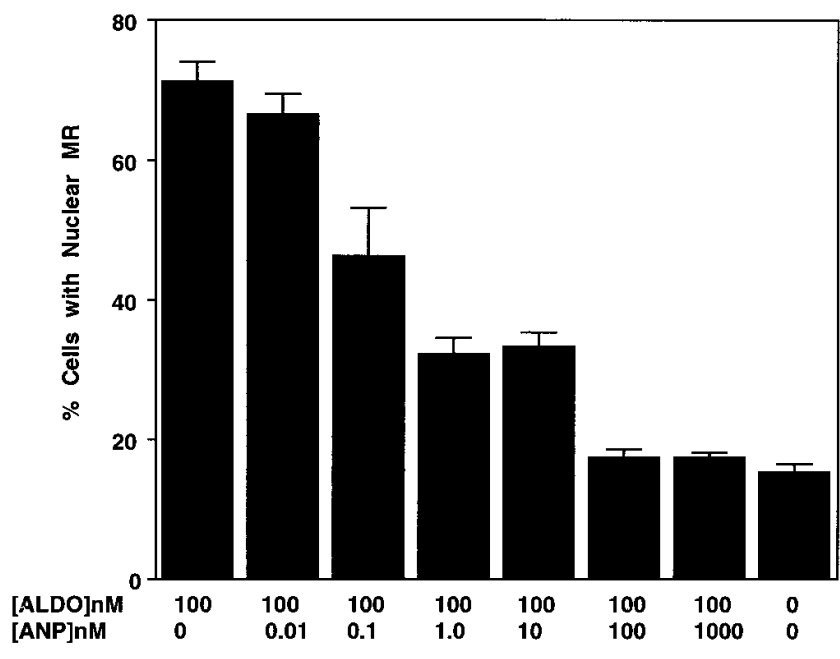

Figure 10. Dose response for ANP inhibition of MR nuclear translocation in surface cells. Surface cells were incubated with $100 \mathrm{nM}$ ALDO in the presence and absence of increasing concentrations of ANP for $60 \mathrm{~min}$ then processed for indirect immunofluorescence using hMRsN. The percentage of cells with nuclear MR was calculated as described in Methods. Results are presented as the mean \pm SEM for $n=4-6$. one induces MR activation. MR from cells incubated with both aldosterone and ANP (Fig. $11 A$, lane 6 ) was also able to bind to the GRE. In cells incubated with ANP alone (Fig. $11 A$, lane 4 ), a minor mobility shift was present. Out of five experiments, four demonstrated a slight mobility shift in cells treated with ANP alone, but it was always less than the intensity of the shifted band observed after exposure of cells to aldosterone or ANP plus aldosterone. In one experiment there was no difference between ANP and the untreated control. These findings confirm that ANP does not inhibit aldosterone-induced MR activation and suggest that ANP by itself may be a weak inducer of activation. The activated GR (Fig. $11 A$, lane 2) eluted with a slightly faster mobility than the MR-GRE band, consistent with the known difference in the molecular mass of GR and MR (2). The greater intensity of the GR mobility shift band compared with that seen with MR probably reflects the
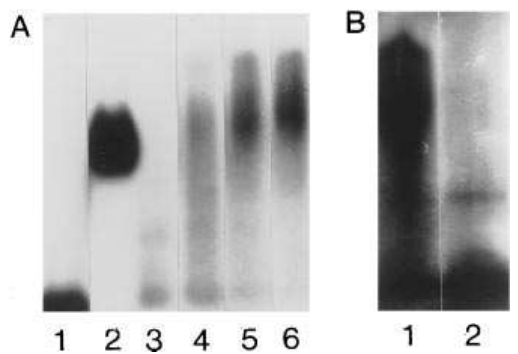

Figure 11. Gel mobility shift assay. Surface cell cytosol was prepared and incubated with $15,000 \mathrm{cpm}$ of $\left[{ }^{32} \mathrm{P}\right] \mathrm{GRE}$ for $1 \mathrm{~h}$ at $4^{\circ} \mathrm{C}$ before electrophoresis as described in Methods. $A$, lane 1 , free DNA; lane 2 , partially purified activated rat liver cytosol

GR; lane 3, cytosol from untreated controls; lane 4, cytosol from cells incubated with ANP; lane 5, cytosol from cells incubated with ALDO; lane 6, cytosol from cells incubated with ALDO plus ANP. $B$, Cytosol from cells exposed to ALDO plus ANP was incubated with $30,000 \mathrm{cpm}$ of [ $\left.{ }^{32} \mathrm{P}\right] \mathrm{GRE}$ for $60 \mathrm{~min}$ followed by addition of nonimmune rabbit serum (lane 1) or hMRsN (lane 2) for $30 \mathrm{~min}$ before electrophoresis. 


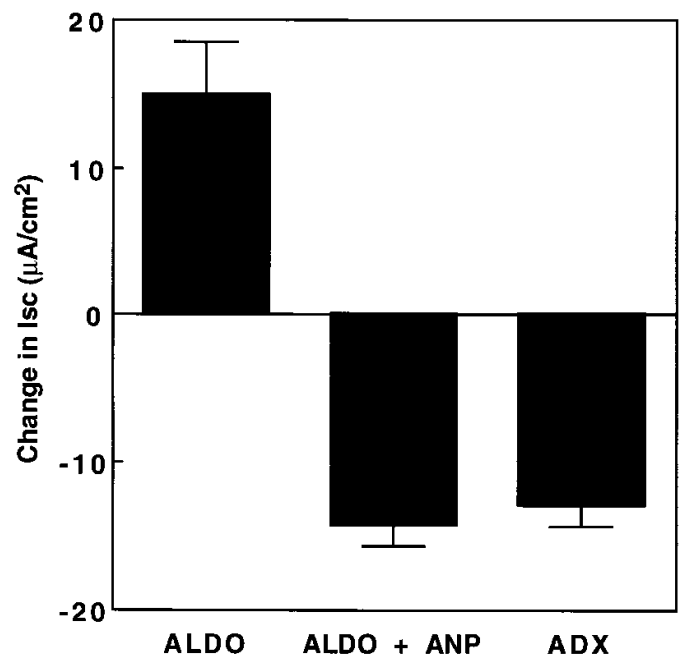

Figure 12. Effect of ANP on ALDO-induced Isc. The most distal segment of distal colon was removed from adrenalectomized rats and mounted in Ussing chamber as described in Methods. Isc was measured in three groups: $A L D O$, Isc was measured for 25 min then 50 nM ALDO was added and Isc was measured for $60 \mathrm{~min}$ after ALDO addition; $A L D O+A N P, 1 \mathrm{nM}$ ANP was added immediately after mounting then $50 \mathrm{nM}$ ALDO was added at $25 \mathrm{~min}$ and Isc was measured for $60 \mathrm{~min}$ after ALDO addition; $A D X$, colon from adrenalectomized rats was studied for an identical time period. Data are presented as the change in Isc at $85 \mathrm{~min}$ (60 min after ALDO addition) versus Isc at $25 \mathrm{~min}$ (immediately before ALDO addition) \pm SEM for $n=7$.

use of partially purified GR versus crude cystosol for the MR assay. Incubation of the colon cell extract with the specific MR antibody hMRsN selectively removed the MR-[ $\left.{ }^{32} \mathrm{P}\right] \mathrm{GRE}$ band confirming that the mobility shifts noted in Fig. 11 $A$, lanes 4-6, represented MR binding to DNA (Fig. $11 B$ ).

Effect of ANP on aldosterone-induced Isc. As previously reported, in the absence of any steroid Isc, PD, and conductance decreased with time (18). ANP by itself did not alter these parameters in the first $25 \mathrm{~min}$, Isc: $57 \pm 3.0 \mathrm{vs}$. $57.9 \pm 2.0 \mu \mathrm{A} / \mathrm{cm}^{2}$ in the absence and presence of ANP, nor did it cause any alteration in these parameters compared with adrenalectomy alone at any time point. After addition of aldosterone, the Isc, transmural PD, and conductance increased. After $1 \mathrm{~h}$ of exposure to aldosterone the Isc had increased by $14.8 \pm 3.6 \mu \mathrm{A} / \mathrm{cm}^{2}$ and PD by $1.7 \pm 0.5 \mathrm{mV}$ while over the same time period the Isc decreased by $13.1 \pm 1.3 \mu \mathrm{A} / \mathrm{cm}^{2}$ and PD decreased by $1.8 \pm 0.4 \mathrm{mV}$ in the absence of aldosterone $(P<0.01)$. Preincubation with ANP completely eliminated the aldosterone-induced increase in Isc so that in each tissue Isc continued to decrease (Fig. 12). At $60 \mathrm{~min}$ the Isc had decreased by $14.4 \pm 1.3 \mu \mathrm{A} / \mathrm{cm}^{2}$ and the transmural PD had decreased by $1.4 \pm 0.2 \mathrm{mV}$, changes no different than those seen in the absence of steroid. Thus, in the presence of ANP no aldosterone-induced conductive $\mathrm{Na}$ absorption could be detected.

\section{Discussion}

These data demonstrate that ANP and cGMP affect two critical steps in MR function in surface cells by decreasing the amount of steroid-bound MR and inhibiting nuclear translocation. ANP inhibition of MR action is consistent with the other known effects of ANP. ANP is a potent antagonist of the re- nin-angiotensin-aldosterone system (22). ANP inhibits renin and aldosterone secretion and antagonizes the vasoconstrictive and proliferative effects of angiotensin II $(22,23)$. ANP has indirect effects on renal $\mathrm{Na}$ handling mediated by changes in systemic hemodynamics, glomerular filtration rate, and medullary blood flow. In addition, in kidney inner medullary collecting duct ANP inhibits Na-conductive transport (24). In the absence of aldosterone, ANP acutely inhibits conductive $\mathrm{Na}$ absorption in kidney inner medullary collecting duct by a cGMPmediated mechanism that is similar to inhibition produced by the $\mathrm{Na}$ conductive channel inhibitor amiloride (24). This may be due to inhibition of a cGMP gated nonselective cation channel (25). However, others have found that ANP inhibition of conductive $\mathrm{Na}$ transport is additive to blockade of the $\mathrm{Na}$ channel with amiloride, suggesting an additional mechanism (26).

Because distal colon surface cells contain high levels of MR and can be isolated easily, the cells are an excellent model in which to study regulation of the MR. However, it has not been established previously that ANP has any effect on Na transport in colon. No other study has examined the effect of ANP on colon exposed to aldosterone. In the absence of stress levels of aldosterone, no conductive Na transport is detectable in distal colon of either intact or adrenalectomized rats while after exposure to aldosterone only conductive $\mathrm{Na}$ absorption is present (27). The only studies to date have examined colon of rats under basal conditions where no conductive transport should be detectable and found no effect of ANP on colonic $\mathrm{Na}$ transport (28-30). The present study documents for the first time that ANP inhibits aldosterone-induced Isc in rat colon. Since tissue was exposed to ANP in vitro, this effect must be mediated at the tissue level and cannot be attributed to ANP-induced changes in mesenteric blood flow or circulating substances known to inhibit conductive $\mathrm{Na}$ absorption. The effect of ANP appears to be specific for the aldosterone-induced Isc since no change in electrical parameters could be detected in the absence of aldosterone. These preliminary studies do not define whether the effect of ANP is mediated at the MR, at the channel, or both. This will require studies beyond the scope of this report. Since ANP was added before exposure of the MR to aldosterone and induction of the channel, a direct inhibitory effect on the MR remains a possible mechanism for ANP inhibition of aldosterone-induced Isc. The time course of ANP inhibition of aldosterone-induced Isc is compatible with the time course of ANP inhibition of MR nuclear translocation.

The physiologic actions of ANP are initiated by binding of ANP to its specific cell membrane receptor. ANP receptors are members of the receptor guanylyl cyclase family and contain an extracellular $\mathrm{NH}_{2}$-terminal ligand binding domain and intracellular COOH-terminal guanylyl cyclase activity (31). The ANP receptor, also known as GC-A, has a higher affinity for ANP than for other natriuretic peptides such as BNP and CNP (15). There is also a truncated ANP receptor lacking $\mathrm{COOH}$-terminal guanylyl cyclase activity that binds all known natriuretic peptides and probably functions as a clearance receptor (ANPR-C) (15). There is little known regarding ANP receptors on distal colon surface and crypt cells. However, in small intestine ANP receptors are localized to the basolateral membrane of the villus (surface) cells (32). ANP is synthesized by colonic enterochromaffin cells, suggesting that ANP may have local paracrine effects (33). The dose-response data for 
ANP inhibition of MR nuclear translocation and MR $\left[{ }^{3} \mathrm{H}\right]$ aldosterone binding were similar and showed a minimum inhibitory concentration of $\sim 100 \mathrm{pM}$ and a maximal effect at $\sim 100$ $\mathrm{nM}$. While the lowest inhibitory ANP concentration is within the upper limits of physiologic ANP levels, the maximum effective concentration is above physiologic levels. There are several possible explanations for this. These studies were done at $30^{\circ} \mathrm{C}$, not $37^{\circ} \mathrm{C}$, no phosphodiesterase inhibitors were used, and stability of ANP during incubations was not assessed. Evidence that ANPs effects in surface cells are mediated by binding to GC-A includes that exogenous cGMP mimics the inhibitory actions of ANP on the amount of steroid-bound MR and on MR nuclear translocation and that the effects of ANP and cGMP are both blocked by inhibition of PKG. Since the ANP clearance receptor is not coupled to guanylyl cyclase activity, these findings cannot be explained by binding to the clearance receptor. Colon contains an additional receptor guanylyl cyclase, GC-C, that serves as the receptor for guanylin and Escherichia coli heat stable enterotoxin (34). However, the extracellular ligand binding domains of the ANP receptor GC-A and the guanylin receptor GC-C share $<10 \%$ homology and even micromolar concentrations of ANP do not activate GC-C (34). Therefore, it is unlikely that the effect of ANP on MR function in surface cells is mediated by GC-C. The observation that cGMP mimicked the effects of ANP on the MR raises the question of whether this is specific for ANP-stimulated cGMP synthesis or if increases in cGMP induced by other pathways (GC-C or soluble GC) would have similar effects on the MR. Our data do not allow distinction between these possibilities.

The magnitude and time course of ANP-induced decreases in steroid-bound MR in the present study are similar to those reported in rat kidney cytosol after in vivo injection of ANP (13). In that study, bolus intravenous injection of ANP decreased the $\mathrm{B}_{\max }$ of the $\mathrm{MR} \sim 50 \%$ in both adrenal intact and adrenalectomized rats. The decrease was first apparent at 90 min after ANP injection and persisted for $180 \mathrm{~min}$. In conjunction with our data in isolated surface cells, it suggests ANP has a direct inhibitory effect on the amount of steroid-bound MR in two classic aldosterone-responsive tissues. The 90-150-min lag period before ANP inhibits steroid-bound MR is consistent with ANP-induced decreases in MR protein. Further studies are needed to determine the mechanism of this effect.

There are few data available addressing whether ANP or cGMP also alter function of other steroid hormone receptors. Horiuchi et al. reported that intravenous injection of ANP also decreased the $B_{\max }$ of the GR in rat kidney cytosol (13). However, GR binding was calculated as the low affinity component of $\left[{ }^{3} \mathrm{H}\right]$ aldosterone binding, not by direct measurement. Previous studies using cGMP have yielded conflicting results. cGMP decreases the number of steroid-bound GR in human fibroblasts by approximately one-third but has no effect on GR steroid binding in a mouse thymoma cell line $(35,36)$. In rat uterine cells, cGMP has no effect on PR steroid binding or protein (37). cGMP actually increases estrogen receptor binding in endometrial cells but this occurs within 5-15 min even in isolated cytosol and thus probably involves a different mechanism than the delayed effect on MR steroid binding observed in kidney and colon surface cells (38).

In contrast to the delayed decrease in $\left[{ }^{3} \mathrm{H}\right]$ aldosteronebound MR, ANP rapidly and reversibly inhibits MR nuclear translocation in surface cells. This effect is mediated by PKG and is due to impaired nuclear import and not to increased nu- clear export. Steroid receptor nuclear entry is mediated by short sequences called NLS which target a protein to the nucleus by interaction with NLS receptors (39). The MR, like the GR, contains a dominant hormone dependent NLS and is therefore cytoplasmic in the absence of hormone $(9,10)$. Hormone binding causes a conformational change in the MR, dissociation of hsp90, and exposure of the NLS (9, 40). Since there is no change in $\left[{ }^{3} \mathrm{H}\right]$ aldosterone binding until much later, the rapid inhibition of MR nuclear translocation by ANP cannot be due to decreased aldosterone binding. Our data demonstrating that ANP does not inhibit MR activation as assessed by DEAE-cellulose chromatography and gel mobility shift assay imply that ANP does not inhibit the conformational change, dissociation of hsp90, or exposure of the DNA-binding domain associated with activation. Therefore, the most likely mechanism for ANP inhibition of MR nuclear translocation is cGMPinduced alterations in the nuclear import mechanism. Pratt has suggested that steroid receptor nuclear translocation requires interaction of receptor, perhaps mediated by hsp56, with the cytoskeletal proteins vimentin, actin, and tubulin (3). cGMP inhibits nuclear translocation of another steroid receptor, the vitamin D receptor (VDR), in fibroblasts by altering the interaction of VDR with tubulin $(41,42)$. Since PKG can phosphorylate tubulin and microtubule-associated proteins, it has been postulated that exogenous cGMP prevents activated VDR dissociation from tubulin and thereby inhibits VDR nuclear translocation (41). Another possible relationship between ANP and the cytoskeleton is suggested by a report that ANP and cGMP cause dissociation of F-actin fibers in glomerular epithelial cells (43). These data suggest that ANP might inhibit MR nuclear translocation by altering the interaction of the MR with the cytoskeletal protein transport system. Our data do not exclude alternative mechanisms. For example, PKG might directly or indirectly phosphorylate MR on amino acids flanking the NLS and thereby inactivate the NLS (44).

In crypt cells, ANP had no effect on either MR [ $\left.{ }^{3} \mathrm{H}\right]$ aldosterone binding or nuclear translocation. This could be due to lack of ANP receptors. However, cGMP also had different effects in surface and crypt suggesting differences in intracellular effector systems. Further differences between surface and crypt cells are demonstrated by the disparity in the response to inhibition of PKG with KT5823. In surface cells, KT5823 had no significant effect on $\left[{ }^{3} \mathrm{H}\right]$ aldosterone-bound $\mathrm{MR}$ in the absence of exogenous cGMP or ANP but blocked the inhibitory effects of exogenous cGMP and ANP. These data suggest that basal endogenous cGMP is not an important regulator of surface MR function and that the effects of adding ANP or cGMP are mediated by PKG. The cGMP and KT5823 data in crypt are more difficult to explain. In crypt cells KT5823 increased $\left[{ }^{3} \mathrm{H}\right]$ aldosterone-bound MR by $\sim 40 \%$. This suggests that there is elevated basal PKG activity in crypt which inhibits MR steroid binding. This may, in part, explain why Scatchard analysis indicates crypt cells have less MR per cell than surface cells (10). It is unlikely that KT5823 increases crypt cell steroid-bound MR by a nonspecific action since any nonspecific effects should also have been apparent in surface cells. The concentration of KT5823 used $(500 \mathrm{nM})$ is well below the $K_{\mathrm{i}}$ of KT5823 for PKA $(>10 \mu \mathrm{M})$ and PKC $(4 \mu \mathrm{M})(20)$. We cannot exclude that KT5823 inhibits some other kinase that is present in crypt but not in surface and thereby increases $\left[{ }^{3} \mathrm{H}\right]$ aldosterone-bound MR. Exogenous cGMP also increased $\left[{ }^{3} \mathrm{H}\right]$ aldosterone-bound MR and this was not inhibited by KT5823. This 
suggests that the predominant effect of exogenous cGMP occurs through a non-PKG-mediated pathway, perhaps because PKG is already active at baseline. There are both cGMP-stimulated and cGMP-inhibited phosphodiesterases (19). It is possible that in crypt exogenous cGMP upregulates MR properties by altering phosphodiesterase activity, perhaps via a cAMPmediated pathway. Regardless of the mechanism involved, these data clearly demonstrate that regulation of MR function is cell specific. These differences between regulation of MR function in two native target cells could translate physiologically in vivo into the ability to control MR properties and therefore aldosterone responsiveness independently in individual target cells.

\section{Acknowledgments}

The authors thank Dr. Tin-Chen Hsu and Dr. Gerald Litwack for providing the GRE and for help in establishing the mobility shift assay.

This study was supported by Grant-In-Aid 92013120 from the American Heart Association and National Institutes of Health grant ROI DK45504 to G. Schulman.

\section{References}

1. Gustafsson, J.A., J. Carlstedt-Duke, L. Poellinger, S. Okret, A.C. Wilkstrom, M. Bronnegard, M. Gillner, Y. Dong, K. Fuxe, A. Cintra, et al. 1987. Biochemistry, molecular biology, and physiology of the glucocorticoid receptor. Endocr. Rev. 8:185-234.

2. Arriza, J.L., C. Weinberger, G. Cerelli, T.M. Glaser, B.L. Handelin, D.E. Housman, and R.M. Evans. 1989. Cloning of human mineralocorticoid receptor complementary DNA: structural and functional kinship with the glucocorticoid receptor. Science (Wash. DC). 237:268-275.

3. Pratt, W.B. 1993. The role of heat shock proteins in regulating the function, folding, and trafficking of the glucocorticoid receptor. J. Biol. Chem. 268: 21455-21458.

4. Smith, D.F., and D.O. Toft. 1993. Steroid receptors and their associated proteins. Mol. Endocrinol. 7:1704-1711.

5. Smith, D.F. 1993. Dynamics of heat shock protein 90-progesterone receptor binding and the disactivation loop model for steroid receptor complexes. Mol. Endocrinol. 7:1418-1429.

6. Tsai, M.-J., and B.W. O'Malley. 1994. Molecular mechanisms of action of steroid/thyroid receptor superfamily members. Annu. Rev. Biochem. 63:451486.

7. Rafestin-Oblin, M.-E., B. Couette, M. Lombes, and E.-E. Baulieu. 1991. Biochemical studies of the mineralocorticosteroid receptor: oligomeric structure and anti-hormone action. In Aldosterone: Fundamental Aspects. J.P. Bonvalet, N. Farman, M. Lombes, and M.E. Rafestin-Oblin, editors. Colloque INSERM/John Libbey Eurotex Ltd., Paris, London. 55-64.

8. Cidlowski, J.A., D.L. Bellingham, F.E. Powell-Oliver, D.B. Oubahn, and M. Sar. 1990. Novel antipeptide antibodies to the human glucocorticoid receptor: recognition of multiple receptor forms in vitro and distinct localization of cytoplasmic and nuclear receptors. Mol. Endocrinol. 4:1427-1437.

9. Picard, D. 1991. Hormonal regulation of mineralocorticoid receptor activity. In Aldosterone: Fundamental Aspects. J.P. Bonvalet, N. Farman, M. Lombes, and M.E. Rafestin-Oblin, editors. Colloque INSERM/John Libbey Eurotext Ltd., Paris, London. 3-12.

10. Schulman, G., N.M. Robertson, I.B. Elfenbein, D. Eneanya, G. Litwack, and C.P. Bastl. 1994. Mineralocorticoid and glucocorticoid receptor steroid binding and localization in colonic cells. Am. J. Physiol. 266:C729-C740.

11. Orti, E., J.E. Bodwell, and A. Munck. 1992. Phosphorylation of steroid hormone receptors. Endocr. Rev. 13:105-128.

12. Power, R.F., S.K. Mani, J. Codina, O.M. Comeely, and B.W. O'Malley. 1991. Dopaminergic and ligand-independent activation of steroid hormone receptors. Science (Wash. DC). 254:1636-1639.

13. Horiuchi, M., N. Kohashi, H. Nishiyama, J. Hama, T. Takenaka, H. Kondo, and R. Katori. 1989. Regulation of aldosterone receptor in rat kidney cytosol by atrial natriuretic factor. Hypertension (Dallas). 13:334-340.

14. Garbers, D.L. 1992. Guanylyl cyclase receptors and their endocrine, paracrine, and autocrine ligands. Cell. 71:1-4.

15. Koller, K.J., and D.V. Goeddel. 1992. Molecular biology of the natriuretic peptides and their receptors. Circulation. 86:1081-1088.

16. Bastl, C.P., G. Schulman, and E.J. Cragoe. 1992. Glucocorticoids inhibit colonic aldosterone-induced conductive $\mathrm{Na}^{+}$absorption in adrenalectomized rat. Am. J. Physiol. 263:F443-F452.

17. Robertson, N.M., G. Schulman, S. Karnik, E. Alnemri, and G. Litwack. 1993. Demonstration of nuclear translocation of the mineralocorticoid receptor using an anti-MR antibody and confocal laser scanning microscopy. Mol. Endocrinol. 7:1226-1239.

18. Bastl, C.P., L. Bressler, G. Schulman, M. Mendez, and E.J. Cragoe. 1991. Low dose glucocorticoids maintain Na-H exchange in the distal colon of the adrenalectomized rat. Am. J. Physiol. 261:F545-F553.

19. Conti, M., S.-L.C. Jin, L. Monaco, D.R. Repaske, and J.V. Swinnen. 1991. Hormonal regulation of cyclic nucleotide phosphodiesterases. Endocr. Rev. 12:218-234.

20. Stoll, L.L., and A.A. Spector. 1993. Lysophosphatidycholine causes cGMP-dependent verapamil-sensitive $\mathrm{Ca}^{2+}$ influx in vascular smooth muscle cells. Am. J. Physiol. 264:C885-C893.

21. Schulman, G., A. Miller-Diener, G. Litwack, and C.P. Bastl. 1986. Characterization of the rat colonic aldosterone receptor and its activation process. $J$. Biol. Chem. 261:12102-12108.

22. Cogan, M.G. 1990. Atrial natriuretic peptide. Kidney Int. 37:1148-1160.

23. Appel, R.G. 1992. Growth-regulatory properties of atrial natriuretic factor. Am. J. Physiol. 262:F911-F918.

24. Zeidel, M.L. 1993. Hormonal regulation of inner medullary collecting duct sodium transport. Am. J. Physiol. 265:F159-F173.

25. McCoy, D.E., S.E. Guggino, and B. Stanton. 1995. The renal cGMPgated cation channel: its molecular structure and physiological role. Kidney Int. 48:1125-1133.

26. Sonnerberg, H., U. Honrath, and D.R. Wilson. 1990. In vivo microperfusion of inner medullary collecting duct in rats: effect of amiloride and ANF. Am. J. Physiol. 259:F222-F226.

27. Bastl, C.P., H.J. Binder, and J.P. Hayslett. 1980. Role of glucocorticoids and aldosterone in maintenance of colonic cation transport. Am. J. Physiol. 238: F181-F186.

28. Barros, G.J., N. Vakil, J. Gutkowska, J. Sellin, and G.D. Potter. 1990. Atrial natriuretic factor and cyclic guanosine monophosphate: ion transport in rat colon in vitro and in vivo. Gastroenterology. 99:1153-1156.

29. Moriarty, K.J., N.B. Higgs, M. Lees, A. Tonge, T.D. Wardle, and G. Warhurst. 1990. Influence of atrial natriuretic peptide on mammalian large intestine. Gastroenterology. 98:647-653.

30. Vaandrager, A.R., A.G.M. Bot, J. DeVente, and H.R. De Jonge. 1992. Atriopeptins and Escherichia coli enterotoxin STa have different sites of action in mammalian intestine. Gastroenterology. 102:1161-1169.

31. Chinkers, M., and D.L. Garbers. 1991. Signal transduction by guanylyl cyclases. Annu. Rev. Biochem. 60:553-575.

32. Bianchi, C., G. Thibault, A. De Lean, J. Genest, and M. Cantin. 1989. Atrial natriuretic factor binding sites in the jejunum. Am. J. Physiol. 256:G436G441.

33. Gerbes, A.L., W. Nathrath, M. Cantin, and H. Denecke. 1991. Presence of atrial natriuretic factor prohormone in enterochromaffin cells of the human large intestine. Gastroenterology. 101:424-429.

34. Schulz, S., C.K. Green, P.S. Yuen, and D.L. Garbers. 1990. Guanylyl cyclase is a heat-stable enterotoxin receptor. Cell. 63:941-948.

35. Gruol, D.J., N.F. Campbell, and S. Bourgeois. 1986. Cyclic AMP-dependent protein kinase promotes glucocorticoid receptor function. J. Biol. Chem. 261:4909-4914.

36. Oikarinen, J., L. Hamalainen, and A. Oikarinen. 1984. Modulation of glucocorticoid receptor activity by cyclic nucleotides and its implications on the regulation of human skin fibroblast growth and protein synthesis. Biochim. Biophys. Acta. 799:158-165.

37. Aronica, S.M., and B.S. Katzenellenbogen. 1991. Progesterone receptor regulation in uterine cells: stimulation by estrogen, cyclic adenosine $3^{\prime}, 5^{\prime}$ monophosphate, and insulin-like growth factor I and suppression by antiestrogens and protein kinase inhibitors. Endocrinology. 128:2045-2052.

38. Fleming, H., R. Blumenthal, and E. Gurpide. 1983. Rapid changes in specific estrogen binding elicited by cGMP or cAMP in cytosol from human endometrial cells. Proc. Natl. Acad. Sci. USA. 80:2486-2490.

39. Goldfarb, D.S. 1992. Are the cytosolic components of the nuclear, ER, and mitochondrial import apparatus functionally related? Cell. 70:185-188.

40. Rafestin-Oblin, M.-E., M. Lombes, B. Couette, and E.-E. Baulieu. 1992 Differences between aldosterone and its antagonists in binding kinetics and ligand-induced hsp90 release from mineralocorticosteroid receptor. J. Steroid Biochem. Mol. Biol. 41:815-821.

41. Barsony, J., and S.J. Marx. 1991. Rapid accumulation of cyclic GMP near activated vitamin D receptors. Proc. Natl. Acad. Sci. USA. 88:1436-1440.

42. Barsony, J., and W. McKoy. 1992. Molybdate increases intracellular 3',5'-guanosine cyclic monophosphate and stabilizes vitamin D receptor association with tubulin-containing filaments. J. Biol. Chem. 267:24457-24465.

43. Sharma, R., H.B. Lovell, T.B. Weigmann, and V.J. Savin. 1992. Vasoactive substances induce cytoskeletal changes in cultured rat glomerular epithelial cells. J. Am. Soc. Nephrol. 3:1131-1138.

44. Moore, M.S., and G. Blobel. 1993. The GTP-binding protein Ran/TC4 is required for protein import into the nucleus. Nature (Lond.). 365:661-663. 